\title{
A APLICAÇÃO DA TEORIA DO "HATE SPEECH" NAS DECISÕES DO STF: UM ESTUDO DE CASOS
}

\author{
Maria Vital da Rocha \\ Pós Doutoranda em Direito, na Faculdade de Direito da \\ Universidade de Lisboa (clássica). Professora Adjunta de \\ Direito Civil, na Faculdade de Direito da Universidade \\ Federal do Ceará. Professora Titular do curso de graduação \\ em Direito da Faculdade 7 de Setembro. Procuradora \\ Federal (Advocacia Geral da União). \\ mavital@secrel.com.br

\section{Lidiane Moura Lopes} \\ Doutoranda em Direito pela Universidade Federal do \\ Ceará. \\ lidimlopes@hotmail.com
}

RESUMO: O presente artigo tem por finalidade proceder ao estudo da aplicação da Teoria do "Hate Speech", ou discurso do ódio, nas decisões proferidas pelo STF analisando, em especial, a ponderação de interesses entre a manifestação da liberdade de expressão e a limitação à autonomia da vontade em situações que expressam a intolerância movida por preconceitos referentes à origem étnica, ao exercício de cultos religiosos, orientação sexual, contra portadores de deficiência física ou mental, entre outras situações. O tema coloca em discussão ainda o direito à informação e os limites impostos pela censura, sob pena de violação dos direitos personalidade e consequente responsabilidade penal e civil.

PALAVRAS-CHAVE: Teoria do "Hate Speech"; Exercício da liberdade de expressão; Autonomia da vontade; Limitações; Responsabilidade.

The application of the hate speech theory in Brazilian Supreme Court decisions: a case study

ABSTRACT: This article aims to make the study of the application of the Theory of "Hate Speech", or hate speech, the decisions handed down by the Supreme Court analyzed, in particular the balance of interests between the manifestation of freedom of expression and limiting the autonomy the will in situations that express intolerance motivated by prejudice related to ethnic origin, the exercise of religious cults, sexual orientation, against persons with physical or mental disabilities, among other situations. The theme puts in further discussion the right to information and the limits imposed by censorship, under penalty of violation of personality rights and consequent criminal and civil liability.

KEYWORDS: Theory of "Hate Speech"; Freedom of expression exercise; Freedom of choice; Limitations; Liability. 


\section{INTRODUÇÃO}

A Teoria do "Hate Speech" também conhecida como discurso do ódio, da intolerância, ganha cada vez mais importância não apenas no direito comparado, em especial, nos Estados Unidos, mas também na nossa ordem jurídica. A manutenção da paz e da segurança depende, sem dúvida, da harmônica convivência entres os indivíduos, outro não é o ensinamento que extraímos inclusive do texto bíblico ao ordenar como segundo maior mandamento "Amarás o teu próximo como a ti mesmo" (Mt 22:39).

Estudar a Teoria do "Hate Speech" requer uma breve análise acerca dos limites do exercício ao direito de liberdade, considerado de forma ampla, abrangendo a possibilidade de manifestação religiosa, de crença, de pensamento, de imprensa e a censura que lhe é imposta como forma de respeito ao outro, com um conteúdo estabelecido pelo resguardo da dignidade da pessoa humana a direcionar o exercício com responsabilidade da cidadania.

Nosso Texto Constitucional consagra entre os direitos e garantias fundamentais, a liberdade de expressão, de pensamento, de crença, de culto, ao mesmo tempo em que veda toda e qualquer censura de natureza política, ideológica e artística, consoante prescreve o artigo $5^{\circ}$, incisos IV, VI e IX. Nada obstante, há que se estabelecer entre essas normas, aparentemente conflitantes, um espaço de diálogo, o que é possível por intermédio da necessária ponderação de interesses e a busca pela construção dos limites da tolerância.

Nesse sentido, o presente trabalho aborda sob um enfoque prático a aplicação da Teoria do "Hate Speech" no Brasil, em especial, nas decisões proferidas pelo Supremo Tribunal Federal, guardião maior dos reclames envolvendo as violações aos preceitos constitucionais.

A opção pelo estudo da metodologia utilizada nas decisões do STF ao configurar ou não tal prática discriminatória, não nos furta de uma breve análise do histórico da teoria, com ênfase nas decisões emanadas dos tribunais americanos que muito contribuíram para o desenvolvimento de seu conteúdo.

É sabido que os direitos não são absolutos, e essa relativização encontra o espaço necessário para o respeito ao próximo, sob pena de dupla responsabilização: nas esferas civil e penal, razão pela qual dedicamos os dois últimos tópicos à demonstração das consequências do reconhecimento da conduta e os meios de reparação do dano causado.

\section{BREVE HISTÓRICO DO SURGIMENTO DA TEORIA DO "HATE SPEECH" NO DIREITO NORTE-AMERICANO}

A Constituição norte-americana, em vigor desde 1789, introduziu a garantia à liberdade de expressão com a Primeira Emenda ${ }^{1}$ (no ano de 1791). Trata-se, em parte, da consagração do discurso da minoria, no resguardo dos seus direitos, coibindo desarrazoadas manifestações de intolerância. Nos Estados Unidos há um fortalecimento do exercício da liberdade de expressão, notadamente, das informações divulgadas pela imprensa.

No caso citado, entendeu a Corte que o direito à privacidade apesar de importante e de ser reconhecida ainda a inadmissibilidade das interceptações feitas de forma clandestina, há na

\footnotetext{
1 A Constituição americana sofreu vinte e sete alterações, sendo as dez primeiras emendas, conhecidas como Bill of Rights.
} 
situação a necessidade de sobrepor o interesse público à divulgação da notícia, pela relevância que esta assumiu diante dos interesses privados.

A nação norte-americana convive com um paradoxo: é uma das mais (senão a mais) desenvolvida do mundo e, no entanto, ainda não superou os resquícios que os anos de segregação entre brancos e negros impuseram.

Antes de adentrar no discurso do ódio e suas consequências atuais para a nação norteamericana, é importante que se faça um breve relato histórico ${ }^{2}$ da intolerância racial naquele país. Os negros chegaram aos Estados Unidos no final do século XVII na Virgínia. De início vinham como servos e o trabalho visava custear a viagem. No entanto, logo a escravidão tornouse uma atividade legal e o tráfico negreiro uma excelente fonte de renda. Estima-se que no ano de 1860 os negros compunham uma parcela de mais de 4 milhões de escravos contra 500 mil homens livres.

Já no século XVIII os movimentos abolicionistas começam a despontar, em especial, com a chegada à Presidência da República de Abraham Lincoln, um abolicionista declarado. Os Estados do Sul, de tradição escravocrata, acabaram por romper com a federação dando origem à Guerra Civil Americana e fizeram com que Lincoln assinasse a Proclamação da Emancipação, libertando os escravos em 1863. Mas a história de segregação estava apenas começando.

Ainda no século XIX são promulgadas pelos Estados do Sul as chamadas "Leis Jim Crow" que visavam legitimar a discriminação racial e impedir que os negros exercessem o direito ao voto (uma contradição num país que consagrou a frase: "one man, one vote" ou "one person, one vote"). Instalou-se a era da segregação, chegando a tal ponto que era proibida a mistura entre brancos e negros em ambientes públicos (tais como escolas, cinemas, restaurantes), e para evitar a miscigenação era vetado também o casamento. Atingia até as instituições governamentais, a exemplo das Forças Armadas, segregando os negros em quartéis e locais de treinamentos específicos e sempre liderados por brancos, impedindo, inclusive, a ascensão à determinadas patentes.

O século XX traz uma onda de migração dos negros para Estados do norte, meio-oeste e oeste do país, onde a segregação era menor. A figura de Martin Luther King Jr, nascido no ano de 1929, em Atlanta, é um dos mais fortes símbolos da luta pela igualdade racial em solo americano. Há nos Estados Unidos uma longa trajetória voltada para a busca da igualdade que é constantemente atropelada por incidentes onde o ódio supera a racionalidade, seja de brancos contra negros ou vice-versa. O último caso ${ }^{3}$ até o fechamento do presente artigo ocorreu em Dallas, no Estado do Texas, em 7 de julho de 2016, quando pessoas participavam de uma manifestação em razão do assassinato de dois jovens negros pela Polícia ${ }^{4}$. Cerca de 100 policiais acompanhavam a multidão quando um homem armado de fuzil começou a atirar contra os oficiais e teria dito que sua intenção era a de "matar brancos, principalmente policiais brancos".

O chefe das forças de segurança em Dallas, David Brown, é negro. O ataque provocou a morte de 5 policiais e do atirador Micah Johnson, um veterano do Afeganistão, que acabou morto por um robô que explodiu uma bomba. O fato levou o Presidente Barack Obama a afirmar que "quando as pessoas dizem que a vida dos negros importa, isso não quer dizer que a dos brancos

\footnotetext{
2 Os dados históricos foram extraídos do site: http://veja.abril.com.br/historia/morte-martin-luther-king/historia-negrosescravidao-segregacao-igualdade.shtml. Acesso em: 17, de novembro de 2016.

3 Informações extraídas da Revista Veja. Editora Abril. Edição 2486, ano 49, nº 28, de 13 de julho de 2016. p. 54-55. A reportagem recebeu o título de "As vítimas da Raça".

4 No dia 06 de julho em Minnesota, Philando Castile, 32 anos, foi morto por policiais durante uma blitz. Levando sua mãe a declarar que "Nós (os negros) estamos sendo caçados". Já o americano Alton Sterling, de 37 anos, foi morto pela polícia da Luisiana.
} 
não têm relevância". Afirmou ainda que "Essa não é apenas uma questão negra. Não é apenas uma questão hispânica. É questão americana, com a qual todos nós deveríamos nos importar. Cabe a todos nós dizer que podemos fazer melhor do que isso. Somos melhores do que isso" 5 . E em ato realizado no dia 12 de julho de 2016, em homenagem aos policiais mortos lembrou o Presidente 6 que

\begin{abstract}
Também sabemos que séculos de discriminação racial e escravidão não desaparecem simplesmente com o fim da segregação racial. Eles não pararam quando o doutor [Martin Luther] King fez o seu discurso. As relações raciais melhoraram dramaticamente ao longo da minha vida. Aqueles que negam isto estão desonrando as lutas que nos ajudaram a alcançar este progresso [...]. Se você é negro ou branco, todos temos visto a intolerância em nossas próprias vidas em algum momento.
\end{abstract}

Soma-se agora mais uma triste história das consequências que o ódio e a intolerância podem provocar.

\title{
2 UM CASO ESPECIAL: BEAUHARNAIS VERSUS ILLINOIS
}

Historicamente esse caso ocorrido na década de 50 envolvendo a intolerância racial ganhou bastante relevância. Na situação, Beauharnais distribuiu panfletos denominados de "White Circle of America", seguido de um formulário de adesão, na cidade Chicago, cujo conteúdo era uma petição enviada ao Prefeito e à Câmara de vereadores onde manifestava a intenção de "acabar com as usurpações, os abusos e a violação dos direitos dos Brancos, os ataques contra suas propriedades, sua vizinhança e seus parentes pelos Negros”. Clamava ainda pela não mistura das raças.

O caso foi levado à Suprema Corte americana e ficou conhecido como Beauharnais v. Illinois, 343 U.S. 250, restando decidido no ano de 1952 ${ }^{7}$. Processado e julgado, Beauharnais acabou condenado criminalmente pelo Estado de Illinois, cuja legislação penal proibia a discriminação em locais públicos e a atribuição de qualidades negativas às pessoas em razão da raça, da cor ou da crença, em manifesta prática do crime de difamação ${ }^{8}$.

O caso chegou até a Suprema Corte em razão de Beauharnais alegar em sua defesa o direito constitucionalmente assegurado ao exercício da liberdade de expressão. Sem dúvida, há o conflito direto entre o exercício da liberdade e o resguardo da igualdade o que é possível mediante o uso da tolerância no resguardo das minorias discriminadas.

\section{O "HATE SPEECH" NO BRASIL: CASO ELLWANGER}

Para estudar a aplicação da Teoria do "Hate Speech" no Brasil escolhemos um caso emblemático que ficou muito conhecido no meio jurídico, envolvendo Siegfried Ellwanger Castran que foi denunciado pela prática de racismo tendo sido essa recebida no dia 14 de novembro de

\footnotetext{
5 Extraído do site: http:/g1.globo.com/mundo/noticia/2016/07/protesto-contra-violencia-policial-deixa-3-agentes-mortos-e-7-feridos-nos-eua.html, Acesso em: 17, de novembro de 2016.

${ }^{6}$ Discurso extraído do site: http://g1.globo.com/mundo/noticia/2016/07/os-eua-nao-sao-tao-divididos-quanto-parecemdiz-obama-em-dallas.html, Acesso em: 17, de novembro de 2016.

7 Disponível no endereço eletrônico: https://supreme.justia.com/cases/federal/us/343/250/case.html

8 Dispunha a referida legislação: "It shall be unlawful for any person, firm or corporation to manufacture, sell, or offer for sale, advertise or publish, present or exhibit in any public place in this state any lithograph, moving picture, play, drama or sketch, which publication or exhibition portrays depravity, criminality, unchastity, or lack of virtue of a class of citizens, of any race, color, creed or religion which said publication or exhibition exposes the citizens of any race, color, creed or religion to contempt, derision, or obloquy or which is productive of breach of the peace or riots [...]".
} 
1991 pelo juízo da $8^{a}$ Vara Criminal da Comarca de Porto Alegre (RS) e ao final absolvido da imputação. Decisão reformada pela Terceira Câmara Criminal do Egrégio Tribunal de Justiça do Rio Grande do Sul, na data de 31 de outubro de 1996, condenando o réu a dois anos de reclusão e concedendo o benefício do "sursis penal".

Siegfried Ellwanger Castran, proprietário da editora Revisão, que usava em suas obras o pseudônimo de S. E. Castan, foi acusado da prática de racismo por intolerância racial contra os judeus (publicou entre outros: Holocausto: judeu ou alemão? e Acabou o gás!... O fim de um mito $)^{9}$. O autor questionava se de fato existiu o holocausto, defendendo ainda que as reais vítimas seriam os alemães. Consta que o escritor era filiado à corrente denominada de "revisionismo histórico" (Escola Negacionista) contestando os fatos históricos e suas provas, entendia que o holocausto seria um "mito".

O Supremo Tribunal Federal ao decidir a questão manifestou-se sobre o conflito entre a liberdade de expressão (neste caso, com nítido caráter antissemita) e o resguardo dos direitos humanos lato senso, em especial a não discriminação pelo racismo em razão da origem. A alegação da defesa de que não sendo os judeus uma raça, mas sim um povo não afastaria o ato praticado por Ellwanger do crime tipificado como racismo.

Na análise do HC 82.424/RS, o STF apreciou ainda o conteúdo e alcance da expressão "racismo" e após concluir que tal delimitação compreende manifestações antissemitas, passou à construção de uma solução que ponderasse o conflito entre os dois direitos fundamentais discutidos: a liberdade de expressão e o exercício da igualdade (pela não admissão de práticas discriminatórias ou racistas).

Em breve síntese do caso, apresentamos o andamento do processo no STF, oportunidade em que apontamos as ideias defendidas ao longo do julgamento e que demonstram a complexidade do tema.

De início o Ministro Moreira Alves defendeu a tese de que os judeus não podem ser considerados "raça" e concedeu o HC, declarando extinta a punibilidade do paciente, posto que, seria o fato prescritível. Na sequência, o então Ministro Maurício Corrêa questionou a interpretação meramente semântica utilizada pelo ministro Moreira Alves ao analisar o artigo $5^{\circ}$, inciso XLII, da Constituição Federal, por entender que o termo "racismo" é mais amplo do que a mera definição dos tipos raciais (brancos, negros, índios, etc.). Pontuou ainda que o termo "raça" encontra-se superado.

Em manifestação que trataremos mais adiante, o Ministro Marco Aurélio concedeu o Habeas Corpus e defendeu o exercício à liberdade de expressão ${ }^{10}$ (prevalência da liberdade de manifestação de pensamento). Ao final, delimitou o racismo ao preconceito contra os negros.

Eis a decisão final da Suprema Corte sobre o caso

HABEAS-CORPUS. PUBLICAÇAO DE LIVROS: ANTI-SEMITISMO. RACISMO. CRIME IMPRESCRITÍVEL. CONCEITUAÇAO. ABRANGÊNCIA CONSTITUCIONAL.LIBERDADE DE EXPRESSAO. LIMITES. ORDEM DENEGADA. Escrever, editar, divulgar e comerciar livros "fazendo apologia de idéias

9 São obras publicadas por Ellwanger: “O Judeu Internacional”, de Henry Ford; "Holocausto Judeu ou Alemão?”, de S.E. Castan (2 unidades); "A História Secreta do Brasil", de Gustavo Barroso; "Os Conquistadores do Mundo", de Louis Marschalko; "Hitler, Culpado ou Inocente?", de Sérgio Oliveira, e "Os Protocolos dos Sábios de Sião", texto completo e apostilado por Gustavo Barroso (informação extraída do site http://www.stf.jus.br/portal/cms/verNoticiaDetalhe.asp?idConteudo=62411. Acesso em: 17, de novembro de 2016.

${ }^{10}$ Entendemos oportuno citar Noberto Bobbio na clássica "A Era dos Direitos" que ao tratar da intolerância assevera que "é melhor uma liberdade sempre em perigo, mas expansiva, do que uma liberdade protegida, mas incapaz de se desenvolver. Somente uma liberdade em perigo é capaz de se renovar" (1998, p. 214). 
preconceituosas e discriminatórias" contra a comunidade judaica (Lei 7716/89, artigo 20, na redação dada pela Lei 8081/90) constitui crime de racismo sujeito às cláusulas de inafiançabilidade e imprescritibilidade $\left(\mathrm{CF}\right.$, artigo $5^{\circ}$, XLII). [...]” (BRASIL. HC 82.424, Rel. Min. Moreira Alves, Rel. p/ o Acórdão Min. Maurício Corrêa, Tribunal Pleno, DJ de 19/3/2004).

O STJ no julgamento do Habeas Corpus n ${ }^{\circ}$ 169.181/RS, decidido em 27 de agosto de 2012, ratificou o entendimento esboçado sobre o caso anteriormente pelo STF, decidindo por unanimidade, ao final, conhecer parcialmente da ordem de habeas corpus e denega-lhe provimento.

\section{O STF E A PONDERAÇÃo DE INTERESSES NA ANÁLISE DO "HATE SPEECH"}

Houve por parte da doutrina críticas à metodologia utilizada pelo STF na decisão do caso "Ellwanger". A Corte orientou-se pela técnica da "ponderação de interesses", há muito conhecida pelos constitucionalistas. Neste sentido, observa Daniel Sarmento (2009, p. 42) que a posição tomada pelo STF apesar de aplaudida foi alvo de críticas quanto à metodologia adotada.

Discriminações positivas ou ações afirmativas constituem a outra faceta do tema debatido, seu contraponto, pois visam justamente o resguardo e a inclusão das minorias, tais como os afrodescendentes, os indígenas e os portadores de deficiência. Constituem-se em elemento realizador da justiça social e, senão erradicador, ao menos mitigador das desigualdades econômicas, sociais e históricas.

No caso Ellwanger, o STF não fincou uma decisão que deveria ser paradigmática e isso é perceptível pela análise dos votos proferidos, oscilando em teses contrapostas sem o aprofundamento necessário da questão, limitando-se ao final a propor a técnica da ponderação de valores. Não se atentou para o fato de que a discussão central era a prática ou não do racismo pelo paciente. Ademais, se configurada a ilicitude da conduta, jamais poderia o ordenamento jurídico aceitá-la, afastando a necessidade da ponderação na situação.

Eros Roberto Grau (2014, p. 343) analisou o caso em questão refletindo sobre a construção da decisão e criticando o que chama de "supervalorização dos princípios" que entende trazer incertezas incompatíveis com a segurança almejada das decisões judiciais, em especial, de uma Corte Suprema. Observa que naquele julgamento foram tomadas "decisões diametralmente opostas", a saber

Os Mins. Marco Aurélio e Gilmar Mendes fizeram uso da proporcionalidade [...] O
Min. Marco Aurélio ponderando os dois princípios, entendeu que a restrição à liber-
dade de expressão provocada pela condenação à publicação do livro antissemita não
é uma medida adequada, necessária e razoável; não constitui, pois restrição per-
mitida pela Constituição. Para o Min. Gilmar Mendes a restrição à liberdade de
expressão causada pela necessidade de coibir a intolerância racial e de preservar a
dignidade humana é adequada, necessária e proporcional; é portanto permitida
pela Constituição. [grifo nosso]

Na obra "Teoria dos Direitos Fundamentais", Robert Alexy (2015, p. 149) exemplifica algumas situações conflitantes, que caberia à técnica da ponderação resolver, tais como

\footnotetext{
a existência de um direito, garantido à imprensa, de manter sigilo acerca de seus informantes, mesmo nos casos [...] em que [...] o objeto da investigação seja um crime doloso de traição à pátria e os redatores sejam suspeitos de serem os autores do crime, e os informantes, seus cúmplices.
} 
Desta forma, que ao repudiar a prática do "hate speech" há uma limitação à autonomia da vontade, não resta dúvida. O problema consiste em justificar essa incursão na livre manifestação da expressão sem configurar o abuso estatal tolhendo o pleno exercício dos direitos da personalidade e ao mesmo tempo delimitar os limites da tolerância.

Interpretando o pensamento de Sigmund Freud trazemos as oportunas conclusões de que "o homem não somente é dotado de instintos de vida e, portanto, de preservação (Eros), mas também de instintos agressivos e/ou de destruição, que por sua vez, precisam conviver em equilíbrio, uma vez que um sustenta o outro" (CALLEGARI et al., p. 16).

Daniel Sarmento (2009, p. 77) em artigo dedicado ao tema propõe a seguinte indagação: até que ponto, deve-se tolerar o intolerante? E a seguir responde citando autores como Karl Popper (que trata do "paradoxo da tolerância") e John Rawls que é preciso estabelecer limites e se necessário punir os intolerantes para resguardo da segurança.

\section{ImplicaÇões Penais: Código Penal e Lei No 7.716/89}

No ordenamento pátrio, nosso Código Penal brasileiro (Decreto-Lei n ${ }^{\circ} 2.848 / 1940$ ) prevê no Capítulo V do Título III, os crimes contra a honra, na seguinte ordem: calúnia (art. 138); difamação (art. 139); e a injúria (art. 140 - animus injuriandi). Doravante faremos uma breve análise dos tipos penais mencionados, suas consequências e entrelaçamento com o assunto estudado.

O crime de calúnia consiste na imputação de fato definido como crime sabendo que esta falsa, seja porque não ocorreu ou a autoria está errada. Há a nítida intenção de prejudicar a vítima. O CP prevê a aplicação de pena de detenção que varia de seis meses a dois anos, e multa ${ }^{11}$. Já no crime de difamação também há a imputação de fato, mas que não é criminoso, porém desonroso à vítima, podendo ser ou não verdadeiro. A pena é de detenção, de três meses a um ano, e multa ${ }^{12}$. Os dois crimes são, em regra, de ação penal privada, cuja titularidade é do querelante (ofendido) e a peça inaugural é a queixa-crime ${ }^{13}$.

O crime de injúria está previsto no artigo 140 do CP nos seguintes termos: injuriar alguém, ofendendo-lhe a dignidade ou o decoro. Cominando a pena de detenção, de um a seis meses, ou multa. Dedicaremos uma atenção maior a este tipo penal em razão da similitude que guarda com o crime de racismo, não raras vezes causando confusão quanto ao verdadeiro enquadramento legal.

A injúria é um crime contra a honra subjetiva, exigindo que o sujeito passivo tenha capacidade suficiente para entender a expressão lesiva à sua honra (atribuição de uma qualidade negativa). Há ofensa à dignidade (valores morais) ou ao decoro (atingindo o respeito ou as características físicas ou intelectuais) da vítima, como por exemplo, chama-la de ladrão, gigolô, safado, mau caráter, macaco, entre outras expressões depreciativas.

\footnotetext{
${ }^{11}$ Art. 138 - Caluniar alguém, imputando-lhe falsamente fato definido como crime: Pena - detenção, de seis meses a dois anos, e multa.

${ }^{12}$ Art. 139 - Difamar alguém, imputando-lhe fato ofensivo à sua reputação: Pena - detenção, de três meses a um ano, e multa.

${ }^{13}$ Procede-se mediante ação penal pública condicionada à requisição do Ministro da Justiça quando a ofensa atinge a honra do Presidente da República, ou de chefe de governo estrangeiro. E ainda mediante representação do ofendido quando é praticada contra funcionário público, em razão de suas funções.
} 
Ocorre que o Código Penal prevê ainda a chamada "injúria preconceituosa" ou "racismo impróprio"14 exigindo do sujeito ativo um especial fim de agir, qual seja, discriminar a vítima (pessoa determinada) em razão da sua raça, cor, etnia, religião, origem, ou a condição de pessoa idosa ou portadora de deficiência. Trata-se de um crime de ação penal pública condicionada à representação do ofendido, afiançável e prescritível.

Antes de adentrar na análise da Lei $n^{\circ} 7.716 / 89$ importa observar o tratamento constitucional dado ao racismo e o repúdio às práticas discriminatórias nos seguintes preceitos:

\footnotetext{
Art. $3^{\circ}$ Constituem objetivos fundamentais da República Federativa do Brasil: IV promover o bem de todos, sem preconceitos de origem, raça, sexo, cor, idade e quaisquer outras formas de discriminação.

Art. $4^{\circ}$ A República Federativa do Brasil rege-se nas suas relações internacionais pelos seguintes princípios: [...]

VIII - repúdio ao terrorismo e ao racismo.
}

Conforme se observa trata-se de um dos objetivos fundamentais e também um princípio norteador. Ademais, já no artigo $1^{\circ}$, inciso III temos como um dos fundamentos da República Federativa do Brasil, a dignidade da pessoa humana, sendo um dos bens jurídicos tutelados pela Lei antirracismo, ao lado da tutela da igualdade.

$\mathrm{O}$ artigo $5^{\circ}$ do Texto Constitucional assevera em seu caput que "todos são iguais perante a lei, sem distinção de qualquer natureza [...]" e prossegue dispondo que "a prática do racismo constitui crime inafiançável e imprescritível, sujeito à pena de reclusão, nos termos da lei” (inciso XLII).

A prática de uma infração penal possibilita ao Estado a aplicação da sanção prevista em lei (exercício do ius puniendi). No entanto, em razão da segurança jurídica, a pretensão punitiva estatal encontra um limite na previsão legal de um lapso temporal que deve ser observado e findo o qual há a perda do direito de punir ou de executar a pretensão punitiva. Conclui-se, portanto, que a prescrição é uma sanção aplicada ao Estado e tem como consequência a extinção da punibilidade, consoante prevê o artigo 107, inciso IV, $1^{\text {a }}$ parte do Código Penal. Ensina Paulo Queiroz que a prescrição é uma das causas extintivas da punibilidade mais importante, posto que extingue tanto a pretensão punitiva quanto a executória e conclui numa observação crítica que

[...] como regra, vigora o princípio da prescritibilidade de todos os crimes, de ação penal pública ou privada, hediondos ou não. Mas a Constituição previu uma exceção ao declarar imprescritíveis: a prática do racismo e a ação de grupos armados, civis ou militares, contra a ordem constitucional e o Estado Democrático (art. $5^{\circ}$, XLII e XLIV), exceção injustificável, uma vez que crimes tão ou mais graves são passíveis de prescrição (latrocínio, homicídio, etc). Também são imprescritíveis, em geral, os chamados crimes internacionais, de competência dos tribunais internacionais, a exemplo dos crimes de genocídio, contra a humanidade, de guerra e de agressão (art. 29), previstos no Estatuto de Roma (art. $5^{\circ}$ ), que criou o Tribunal Penal Internacional (2013, p. 590).

A Lei $n^{\circ} 7.716 / 86$ que define os crimes resultantes de preconceito de raça ou de cor, conhecida como Lei de Racismo, especificamente, no art. 20 dispõe que: "Praticar, induzir ou incitar a discriminação ou preconceito de raça, cor, etnia, religião ou procedência nacional. Pena: reclusão de um a três anos e multa". O que vem ao encontro da previsão contida na Convenção Internacional sobre a Eliminação de Todas as Formas de Discriminação Racial, de 1969, prevendo em seu artigo IV, alínea "a" que os Estados partes se comprometem a

\footnotetext{
${ }^{14}$ Art. 140. $\S 3^{\circ}$. Se a injúria consiste na utilização de elementos referentes a raça, cor, etnia, religião, origem ou a condição de pessoa idosa ou portadora de deficiência: Pena - reclusão de um a três anos e multa.
} 
Declarar delitos puníveis por lei, qualquer difusão de ideias baseadas na superioridade ou ódio raciais, qualquer incitamento à discriminação racial, assim como quaisquer atos de violência ou provocação a tais atos, dirigidos contra qualquer raça ou qualquer grupo de pessoas de outra cor ou de outra origem técnica, como também qualquer assistência prestada a atividades racistas, inclusive seu financiamento.

O crime de racismo pressupõe em regra segregação e atinge uma coletividade (sujeitos indeterminados). Discrimina-se toda uma raça e não uma pessoa específica. Conforme dito anteriormente, diferente da injúria, esse crime é inafiançável e imprescritível. O Conselho Nacional de Justiça $(\mathrm{CNJ})$ também ilustra uma situação em que se configurou o racismo ${ }^{15}$

$1^{\text {a }}$ Turma Criminal do TJDFT manteve uma condenação por crime de racismo de um homem que se autodenomina "skinhead" e que fez apologia ao racismo contra judeus, negros e nordestinos em página da internet. De acordo com os desembargadores, que mantiveram a condenação à unanimidade, "o crime de racismo é mais amplo do que o de injúria qualificada, pois visa atingir uma coletividade indeterminada de indivíduos, discriminando toda a integralidade de uma raça. No caso, o conjunto probatório ampara a condenação do acusado por racismo".

Ademais, a análise do art. 20 da Lei nº 7.716/86 revela a opção do legislador em restringir a abrangência das situações que configurariam a prática do racismo, quais seja, o preconceito decorrente de raça cor, etnia, religião ou procedência nacional, relegando outras como a discriminação decorrente de opção sexual. E foi justamente essa situação que levada ao STF em denúncia oferecida pelo Procurador Geral da República contra o parlamentar que publicou no Twitter a seguinte frase: "a podridão dos sentimentos homoafetivos leva ao ódio, ao crime, à rejeição", acabou rejeitada por entender a $1^{\text {a }}$ Turma da Corte Suprema tratar-se de fato atípico, nos seguintes termos:

\begin{abstract}
Ante a atipicidade da conduta, a $1^{\text {a }}$ Turma não recebeu denúncia oferecida contra Deputado Federal que teria publicado na rede social "twitter" manifestação de natureza discriminatória em relação aos homossexuais. A Turma destacou que o artigo 20 da Lei 7.716/1989 — assim como toda norma penal incriminadora — possui rol exaustivo de condutas tipificadas, cuja lista não contempla a discriminação decorrente de opção sexual [...]. O Ministro Roberto Barroso consignou que o comentário do parlamentar teria sido preconceituoso, de mau gosto e extremamente infeliz. Aduziu, entretanto, que a liberdade de expressão não existiria para proteger apenas aquilo que fosse humanista, de bom gosto ou inspirado. Ressaltou que seria razoável entender que o princípio da dignidade da pessoa humana $\left(\mathrm{CF}\right.$, art. $1^{\circ}$, III) impusesse um mandamento ao legislador para que tipificasse condutas que envolvessem manifestações de ódio ("hate speech"). Ponderou que haveria um projeto de lei nesse sentido em discussão no Congresso Nacional. O Ministro Luiz Fux acrescentou que o STF, ao julgar a legitimação da união homoafetiva, entendera que a homoafetividade seria um traço da personalidade e que, portanto, ela não poderia trazer nenhum discrime, de sorte que a fala do parlamentar, ao mesmo tempo, ultrajaria o princípio da dignidade da pessoa humana e o da isonomia. (BRASIL. Supremo Tribunal Federal. $1^{\text {a }}$ Turma. Inq 3590/DF, Rel. Min. Marco Aurélio, julgado em 12/8/2014).
\end{abstract}

Em síntese, proferir manifestações de natureza discriminatória em relação aos homossexuais não configura o crime do art. 20 da Lei $n^{\circ} 7.716 / 86$. A análise leva em consideração o Princípio da Legalidade, ou melhor, da Estrita Legalidade, observado quanto aos tipos penais incriminadores, sendo a conduta considerada atípica por não se subsumir ao referido tipo legal (Tatbestand). Revela ainda, a necessária preponderância da segurança jurídica ${ }^{16}$.

\footnotetext{
${ }^{15}$ Extraído do site: http://www.cnj.jus.br/noticias/cnj/79571-conheca-a-diferenca-entre-racismo-e-injuria-racial. Acesso em: 17 , de novembro de 2016.

${ }^{16}$ Nas palavras de Nilo Batista, temos que "o princípio da legalidade, base estrutural do próprio estado de direito, é também a pedra angular de todo direito penal que aspire à segurança jurídica, compreendida não apenas na acepção da 'previsibilidade da intervenção do poder punitivo do estado' que lhe confere Roxin, mas também na perspectiva subjetiva do 'sentimento de segurança jurídica' que postula Zaffaroni” (BATISTA, 1990, p. 67).
} 


\section{REPARAÇÃo dO DANO: MÉTOdOS DE MENSURAÇÃo do VALOR DA INDENIZAÇÃO}

Não resta dúvida de que uma vez provocado dolosamente um dano, o curso natural é o seguimento da devida reparação. E em se tratando de condutas que ameaçam direitos tutelados constitucionalmente como os abordados no presente artigo outra não poderia ser a conclusão ao analisarmos o Código Civil, em especial, o Capítulo que disciplina os Direitos da Personalidade, dispondo que

Art. 11. Com exceção dos casos previstos em lei, os direitos da personalidade são intransmissíveis e irrenunciáveis, não podendo o seu exercício sofrer limitação voluntária.

Art. 12. Pode-se exigir que cesse a ameaça, ou a lesão, a direito da personalidade, e reclamar perdas e danos, sem prejuízo de outras sanções previstas em lei.

Se não foi possível evitar a lesão a punição e a consequente reparação do dano causado são consequências que se impõe. No caso da prática do "Hate Speech" vimos que há implicações na seara criminal da qual resultam a consequente imposição da sanção penal, mas que em obediência à independência das instâncias, não obsta que a vítima busque na esfera civil a composição dos prejuízos morais ou materiais suportados.

Selecionamos um caso envolvendo o julgamento de uma apelação pelo Tribunal de Justiça de São Paulo (Apelação nº 0192984-85.2012.8.26.0100), cuja apelante Uni - União Nacional das Entidades Islâmicas, e apelado Google Brasil Internet Ltda. Segundo dados trata-se de uma Ação Cominatória Cumulada com Indenização e cujo julgamento ficou assim estabelecido

\footnotetext{
Pedido de remoção da internet do vídeo intitulado "Inocência dos Muçulmanos". Conflito entre a liberdade artística e de expressão com a liberdade religiosa. Na colidência de tais princípios, no caso, devem prevalecer os primeiros. Nas situações limítrofes, a liberdade de expressão deve prevalecer. Indenização que, por sua vez, se revela de todo descabida, na medida em que não é dado ao provedor exercer controle ou fiscalização prévia sobre o conteúdo disponibilizado. Sentença confirmada. Recurso desprovido. (BRASIL. Tribunal de Justiça de São Paulo. Apelação n ${ }^{\circ} 0192984$ 85.2012.8.26.0100)
}

No caso em questão, a parte apelante argumentou que o conteúdo do vídeo continha explícita manifestação preconceituosa e ofensiva ao Islã, suscitando o ódio e intolerância religiosa. Ocorre que em $1^{\circ}$ grau, a sentença também julgou improcedente a demanda, o que foi conforme visto, confirmado pelo Tribunal. A decisão foi escolhida por citar expressamente o termo "Hate Speech"

\footnotetext{
Sob o prisma do conteúdo, não há qualquer frase discriminatória ou reveladora de ódio contra os muçulmanos o denominado hate speech, na letra da música em questão. Aliás, a canção sequer menciona ou faz alusão, positiva ou negativa, ao islamismo e seus seguidores (BRASIL. Tribunal de Justiça de São Paulo. Apelação n ${ }^{\circ}$ 0192984-85.2012.8.26.0100)
}

A utilização das redes sociais como forma de propagação do ódio tornou-se prática comum que precisa ser coibida, sem dúvida o reconhecimento da responsabilidade e a imposição da sanção e condenação à indenização são os meios que o Estado tem para frear a propagação da intolerância. 


\section{CONCLUSÃO}

O discurso do ódio ou mais conhecido como Teoria do "Hate Speech" ganha contornos relevantes numa era em que predomina o acesso à informação e a rapidez na propagação de notícias via rede mundial de computadores relativiza as fronteiras. No entanto, se a globalização e os recursos tecnológicos uniram os "mundos" o ódio e a intolerância ainda dividem uma nação.

Estabeleceu-se um confronto, ao menos aparente, entre alguns direitos assegurados constitucionalmente, quais sejam: o exercício da liberdade de expressão e manifestação do pensamento (expressão da autonomia da vontade como direito da personalidade, consoante prescreve nossa Constituição Federal e o Código Civil dedica um Capítulo) versus o resguardo da igualdade e o repúdio a todas as formas de discriminação.

A livre manifestação das ideias por todas as formas de expressão assegura o pleno exercício da personalidade, mas precisa compatibilizar-se com a ordem jurídica global, numa interpretação sistemática em que a ponderação de interesses encontra amparo na realização do Princípio da Dignidade da Pessoa Humana.

Nosso Supremo Tribunal Federal chamado a manifestar-se em situações em que há a colisão desses direitos, optou pela adoção da técnica da ponderação de interesses, criticada no âmbito doutrinário em razão das argumentações conflitosas que se construíram e da necessidade de assegurar o mínimo de segurança jurídica por intermédio da criação de uma verdadeira Teoria da Decisão, ainda não alcançada.

Saliente ainda que as condutas configuradoras do "Hate Speech" ou incitamento ao ódio e à intolerância são na maioria das vezes também tipificadas como crime no nosso ordenamento, seja no Código Penal com o tipo da injúria preconceituosa ou na Lei 7.716/89, que trata do crime de racismo.

Há, outrossim, a possibilidade de uma vez configurada a ofensa (e a lesão à personalidade e à honra) a consequente obrigação de reparar o dano causado que dever ser pleiteada pela vítima na instância civil. E por vítima, entenda-se, inclusive, uma coletividade ofendida.

\section{REFERÊNCIAS}

ALEXY, Robert. Teoria dos Direitos Fundamentais. Trad. Virgílio Afonso da Silva. 2. ed. 4. tir. São Paulo: Malheiros, 2015.

BATISTA, Nilo. Introdução Crítica ao Direito Penal Brasileiro. Rio de Janeiro: Revan, 1990. BOBBIO, Norberto et all. Dicionário de Política. Vol.1. 11. ed. Brasília, DF: Universidade de Brasília, 1998.

A era dos Direitos. Trad. Carlos Nelson Coutinho. São Paulo: Campus, 1990.

BRASIL. Supremo Tribunal Federal. Crime de racismo e anti-semitismo: um julgamento histórico no STF: habeas corpus. 82.424/RS. Brasília

CALLEGARI, André Luís. et al. $\mathbf{O}$ crime de Terrorismo: Reflexões críticas e comentários à Lei de Terrorismo: de acordo com a Lei $n^{0}$ 13.260/2016. Porto Alegre: Livraria do Advogado, 2016.

GRAU, Eros Roberto. O direito posto e o direito pressuposto. 9. ed. São Paulo: Malheiros, 2014. 
HABIB, Gabriel. Leis Penais Especiais. Tomo II. 5. ed. Salvador: JusPodivm, 2014.

JABUR, Gilberto Haddad. Liberdade de pensamento e direito à vida privada: Conflitos entre Direitos da Personalidade. São Paulo: Revista dos Tribunais, 2000.

MELlO, Celso Antônio Bandeira de. Conteúdo Jurídico do Princípio da Igualdade. 3. ed. 12. tir. São Paulo: Malheiros, 2004.

MEYER-PFLUG, Samantha Ribeiro. Liberdade de expressão e discurso de ódio. São Paulo: Revista dos Tribunais, 2009.

NOVELINO, Marcelo. Direito Constitucional. 3. ed. São Paulo: Gen/Forense, 2009.

PRADO JÚNIOR, Caio. Formação do Brasil Contemporâneo. São Paulo: Brasiliense, 2006.

QUEIROZ, Paulo. Curso de Direito Penal. Vol. 1. Parte Geral. 9. ed. Salvador: JusPodivm, 2013.

SARLET, Ingo Wolfgang; MARINONI, Luiz Guilherme; MITIDIERO, Daniel. Curso de Direito Constitucional. 4. ed. São Paulo: Saraiva, 2015.

SARMENTO, Daniel. A Liberdade de Expressão e o Problema do "Hate Speech". In: Leituras Complementares de Direito Civil. O direito civil-constitucional em concreto. Organizador: Cristiano Chaves. 2. ed. Salvador: JusPodivm, 2009. p. 39-95.

STRECK, Lenio Luiz. O que é isto: decido conforme minha consciência? 4. ed. Porto Alegre: Livraria do Advogado, 2013.

VALENTE, Ana Lúcia. Ser Negro no Brasil de Hoje. 16. ed. São Paulo: Moderna, 1994. 